Universitas Banten Jaya

\title{
THE EFFECTIVENESS OF LISTEN-DISCUSS STRATEGY (LRD) TOWARD READING STUDENTS' COMPREHENSION
}

\author{
Eka Pebriana $^{1}$, Sisca Wulansari Saputri ${ }^{2}$, Aa Qonaatun ${ }^{3}$ \\ Universitas Banten Jaya \\ Serang, Indonesia \\ ekafebriana1919@gmail.com \\ siscawulansari.saputri@gmail.com \\ aiayangistu@gmail.com
}

\begin{abstract}
This research uses of Listen Read Discuss strategy in reading comprehension. This research was conducted based on formulation of the problem. The objective of this research was to know whether there was any significant effect of using Listen Read Discuss Strategy (LRD) strategy toward reading students' comprehension at the eighth grade of MTS Nurul Falah Kresek. The writer used quantitative research by using quasi experimental research method. Class VIII B as the experimental group which was consisted of 20 students, class VIII A as the control group which was consisted of 20 students. The data were collected by reading test. It can be seen from the result pretest and post-test in experimental and control class. The writer analyzed by using t-test. The result of this research revealed that the post-test scores were better than the pre-test scores. It can be seen from the result of t-test. The criteria of two tailed test with significance level $(\alpha=0.05)$ was $\mathrm{T}$ table $\leq \mathrm{T}$ test $\leq \mathrm{T}$ table: H0 is rejected and $\mathrm{Ha}$ is accepted. The result of computation got $\mathrm{T}$ test $=3.226$ and $\mathrm{T}$ table $=0.444$. It means $0.444<3.226>0.444$. H0 is rejected and Ha was accepted. Based on the conclusion above, it can be concluded that reading comprehension through LRD strategy was more effective for increasing reading comprehension. There is the differences of the teaching learning process between two classes. In the other words, students' reading comprehension that were taught through LRD strategy was higher than those who were not through LRD strategy.
\end{abstract}

Keywords : LRD Strategy, Reading Comprehension.

\section{INTRODUCTION}

As foreign language in Indonesia, English is one of the important subjects because it is an international language. Furthermore, mastering the English well, students need to learn four skill in language, there are listening, speaking, reading and writing. For those skills, Reading is an essential skill for English as a foreign language (EFL) and reading is the most important skill to master by students. When the writer observed at the eighth grade in junior high school of MTS Nurul Falah Kresek Tangerang on Wednesday 20 of December 2017. The writer faced some problems, there are the students have difficulties on process of understanding the ideas in the text, the students are unable to find the idea of 
Volume 2 No. 1, Februari 2019

Universitas Banten Jaya

the text, students also less motivation to join the class in learning reading comprehension.

\section{Problem in Learning Reading Comprehension}

Students with reading problems lack many of the basic components of reading. They cannot read well, even to comprehend the text. They demonstrate multiple problems associated with low comprehension, including poor decoding, fluency (accuracy and speed of reading), and vocabulary (Klingner, 2007). While, vocabulary is the meaning and pronunciation of words that we use in communication (Transkersley, 2003). Therefore, in teaching and learning reading comprehension there are some problems that will be faced by the students, they are as follows:

1) Decoding Students with reading problems have difficulty decoding words and sentences. Children see words and read them without struggling, even if they dont know the meaning of every word.

2) Inference making Numerous studies have demonstrated that poor comprehenders have difficulty drawing inferences when reading.

3) Working memory Verbal working memory weakness may be a consequence of poor language comprehension.

4) Knowledge Without an appreciation of the meanings of words, there can be no comprehension .

5) Prior knowledge Prior knowledge about a text predicts comprehension of it and it is plain that complete lack of knowledge will result in a complete lack of comprehension (Nation, 2016).

Simply, (Colins.et al. 2004.p.3) reading comprehension is an active process, directed by intentional thinking that allows young readers to make connections between their thinking processes, textual content, and their own knowledge, expectations, and purpose of reading. By interviewing them the difficulties maybe caused by several factors such as background knowledge, interest, and attitude. The writer tries to solve of students' problem on learning English reading comprehension with a strategy called Listen-Read-Discuss strategy. Teaching strategy is very important in teaching learning process. Especially In teaching reading comprehension, in order to make an explanation of the materials is clear enough, more variety, more attractive not make the students became bored, and more interesting in reading activities. According to (Manzo,2005,p.10). Listen-Read- 
Volume 2 No. 1, Februari 2019

Universitas Banten Jaya

Discuss (LRD) is heuristic meets these requirements for teachers and students. It offers simple lesson design that can be tried almost immediately and provides several elaborations on the basic design that can be phased in as necessary and appropriate. This is one way to develop a personal program of professional development.

mcKenna (2015:211) Manzo and Casale introduced a technique for improving comprehension that assumes little or no background knowledge for a nonfiction reading selection. Rather than creating a foundation of knowledge that will be useful for co prehending the additional knowledge presented in the selection, the teacher actually covers the content of the selection.

According to Sharon \& Mc. Kenna et.al. (2011:144) there is for summary of steps for teaching reading comprehension by using LRD strategy, there are:

a. Before reading

LRD begins with the teacher presenting the content of the reading selection fully and competely. This may involve approaches such as lecture, demonstration, and discussion. Reading however is not involved.

b. During reading
P-ISSN 2623-0062

E-ISSN 2622-9056

The initial step of the lesson, during which students listen, but don't read, that subsequent reading may seen unnecessary. In fact, LRD has been compared favorablt with other lesson formats. Reading is the best guide by presenting questions and tasks.

c. After reading

Post reading discussion is anchored in the tasks presented by the teacher at the outset. This tasks serve both as a focus for discussion and memory prompt because students can refer to write products that they have created.

Based on Rija Dwiono on his journal, the procedure of teaching reading comprehension through LRD. There are:

\section{a. Pre-Activities}

1) Teacher greets the students.

2) Teacher gives brainstorming to students.

3) Teacher stimulates students' curiosity.

- Students predict what they will read.

4) Facilitating the task. 
- Teacher informs the class that teacher will present presentation which will cover all details of the material, but they will need to read to discover what questions these detail answer.

\section{b. Whilst Activities}

1) Teacher presents the information from the text in the customary lecture style.

2) Reading Give the students times to read the textbook version of the same material.

3) Teacher puts the students into teams and provides times for students to delve into a topic in greater depth.

4) Checking comprehension and facilitating comprehension. Discuss the material students have heard and read. Teacher can use question, adapted and extended from Smith in Manzo \& Casale, these questions recommended for provoking a fruitful discussion following reading:

a. What did you understanding most from what you heard and read?. b. What did you understanding least from what you hear and read?.

c. What questions or though did this lesson raise in your mind about the content and/or about effective reading and learning?.

\section{c. Post Activities Practicing reading skill.}

1) The teacher gives the score and does reflection.

2) The teacher closes the meeting.

Based on the identification of this research, the writer would like to formulate the problem is there any significant effect of students in learning reading comprehension through LRD strategy, and the objective of this problem to know there is any significant effect of students in learning reading comprehension through LRD strategy. And for the use of this research practically can give benefit for the researcher, students, and school environment. The writer can know how to solve problem that connect with this title research. 
Volume 2 No. 1, Februari 2019

Universitas Banten Jaya

\section{RESEARCH METHOD}

In this research, the writer used quasi experimental because in this research the writer has given pre-test an post-test to get the data. Two classes were involved in this research. Only control class which have treatment in this research. Both classes received a pre-test, it used to asses the effect of experimental before the treatment was given and a post-test usually on the same instrument, after the treatment has been given.

According to Gay and Mills (2016:285) in experimental research, the reseracher manipulates at least one independent variable, controls other relevant variables, and observes the effect on one or more dependent variables. Group experimental designs include: preexperimental designs (the one-group posttest only design, the one group pre-test post-test design, and the post-test only design with nonequivalent groups), true experimental designs (the pre-test, posttest, control group design, the post-test only, control group design, and the solomon for-group design), quasiexperimental design (the nonequivalent control group design), the time-serries design, the counterbalanced designs) and factorial designs.

To make this research more clear, the writer provides the research design as follows:

Table : The Research Design

\begin{tabular}{|c|c|c|c|}
\hline Class & $\begin{array}{c}\text { Pre- } \\
\text { Test }\end{array}$ & Treatment & $\begin{array}{c}\text { Post- } \\
\text { Test }\end{array}$ \\
\hline A & $\mathbf{X}$ & $\mathbf{X}$ & $\mathbf{X}$ \\
\hline B & X & $\mathbf{0}$ & X \\
\hline
\end{tabular}

P-ISSN 2623-0062

E-ISSN 2622-9056

This research was conducted at the eighth grade students' of MTS NurulFalahKresek in the academic year 2018. This school located on JL. Raya Kresek km.8 KresekTangerangBanten and started from $11^{\text {th }}$ April until July. According to Gay and Peter Asian (2012:144) sampling is the process of selecting a number of individuals for a study in such a way that the individuals represent the larger group from which they were selected. In this research. In this research, the writer took sample was not random, because in quasi experimental research, the writer should not be used random sampling. total for sampling in this research were 20 students of class. VIII A and VIII B. The data collection technique was pre-test and posttest. In order to get valid information that was supported the writer. The instruments that used by the writer in this research was test. The test consist of Pre-Test and PostTest. In this research, the writer used content validity. Before applying instrument to experimental and control group. The value of its validity should be examined. Based on Huck (2012:81) whereas the best one word synonym for reliability is consistency, the core essence of validity is captured nicely by the word accuracy. From this general perspective, a researcher's data was valid to the extent that the results of the measurement process are accurate.

\section{RESULT AND DISCUSSION}

For the reliability test the criteria of reliability is if $\mathrm{r}_{11}>\mathrm{t}$ table reliable and $\mathrm{r}_{11}<\mathrm{t}$ table unreliable, based on the result of computing showed that $\mathrm{r}_{11}$ of control class was $(0.431)<\mathrm{t}$ table $(0.444)$ and $\mathrm{r}_{11} \mathrm{of}$ 
Volume 2 No. 1, Februari 2019

Universitas Banten Jaya

experimental class was $(0.562)>\mathrm{r}$ table (0.444).

Those mean the tests were unreliable in control class and reliable in experimental class. According to (Hatch.1969.p.244) If $\mathrm{x}^{2}$ count $\geq \mathrm{x}^{2}$ table: it indicates the distribution of the data is not normal. If $x^{2}$ count $\leq x^{2}$ table : it indicates the distribution of data is

\begin{tabular}{lcc}
\multicolumn{1}{c}{ Subject } & $\begin{array}{c}\text { Experimental } \\
\text { Class }\end{array}$ & $\begin{array}{c}\text { Control } \\
\text { Class }\end{array}$ \\
$\begin{array}{l}\text { Total of score } \\
\text { pre-test }\end{array}$ & 6.70 & 6.45 \\
$\begin{array}{l}\text { Mean of pre-test } \\
\text { Total score of }\end{array}$ & 33.5 & 32.25 \\
post-test & 885 & 750 \\
$\begin{array}{l}\text { Mean of post- } \\
\text { test }\end{array}$ & 44.25 & 37.5 \\
$\begin{array}{l}\text { Total score of } \\
\text { gaining }\end{array}$ & 215 & 105 \\
$\begin{array}{l}\text { Mean score of } \\
\text { gaining } \\
\text { Percentage of } \\
\text { score gaining }\end{array}$ & 10.75 & 5.25 \\
normal. & $32 \%$ & $16.2 \%$ \\
\end{tabular}

For the normality test based on the result of calculation, it indicated that $\mathrm{x}^{2}$ count $\leq \mathrm{x}_{\text {table, }}^{2}$ or $=-33.206 \leq 11,070$. Therefore, it can be concluded that the data of post-test of experimental was derived from the population that have normal distribution. Based on the result of calculation above, it indicated that $\mathrm{x}_{\text {count }} \leq$ $\mathrm{x}_{\text {table, }}^{2}$ or $=-21.7 \leq 12.592$. Therefore, it can be concluded that the data of post-test of control class was derived from the population that have normal distribution.

For homogeny test also the criteria of the testing as follows:
If $\mathrm{F}_{\text {count }} \geq \mathrm{F}$ table ; it indicates not homogeny.

If $\mathrm{F}$ count $\leq \mathrm{F}$ table ; it indicates homogeny. (Ridwan.2007.p.14)

Based on the result of the calculation above, it can be concluded that : if $\mathrm{F}$ count $\leq$ $\mathrm{F}$ table or $=1.313 \leq 1.725$. it can be concluded that the variance were homogeny in experimental class. Based on the result of the calculation above, it can be concluded that : if $\mathrm{F}$ count $\leq \mathrm{F}$ table or $=$ $1.688 \leq 1.725$. it can be concluded that the variance were homogeny in control class.

The criteria of two tailed test with significance level $(\alpha=0.05)$ was $\mathrm{T}$ table $\leq$ $\mathrm{T}$ test $\leq \mathrm{T}$ table: $\mathrm{H} 0$ is rejected and $\mathrm{Ha}$ is accepted. The result of computation got $\mathrm{T}$ test $=3.226$ and $\mathrm{T}$ table $=0.444$. It means $0.444<3.226>0.444$. H0 is rejected and Ha was accepted. It can be concluded that there was a significance different of students' reading comprehension between experimental class and control class before they were given the treatment.

\section{Percentage of Score Gaining}

Table 3

\section{Interpretation of the Hypothesis Testing Result.}

After testing the entire result of the research, it was needed to interpret them in relation with the hypothesis of the research. The interpretation of the hypothesis testing result there was a significance difference of students' reading comprehension between those who were taught through reading narrative text by using LRD strategy and conventional method. 
Volume 2 No. 1, Februari 2019

Universitas Banten Jaya

\section{CONCLUSION}

Based on the result of the research and discussion. The writer would like to conclude the hypothesis of the research. In this research, there is any significance effect of students in learning reading comprehension through LRD strategy. It was based on the results of hypothesis testing of pre-test, $\mathrm{T}$ test $=0.583$ and $\mathrm{T}$ table $=0.444$, the criteria of two tailed test with significant level $\alpha=0.05$. H0 was rejected and Ha was accepted. If $\mathrm{T}$ table $\leq$ $\mathrm{T}$ test $\leq \mathrm{T}$ table, the result was $=0.444<$ $0.583>0.444$. it means there was significant difference of students' reading comprehension before they are given the treatment.

The result hypothesis testing of post-test, T-test $=3.226$ and $\mathrm{T}$ table $=0.444$. the criteria of two tailed test with significance level $\alpha=0.05$ was accepted $\mathrm{H}_{\mathrm{a}}$ and were not through LRD strategy.

\section{REFERENCES}

Collins.et al. 2004. Comprehension Process Instructions. New York London: The Guilford Press.

Dwiono, Rija. Listen Read Discuss in Teaching Learning Reading Comprehension. A case study of private senior high school in Lampung.

https://jurnal.uns.ac.id/icalc/article/view/16154 /12994

Gay. Mills.et al. 2012. Educational Research Competencies for Analysis and Applications.Tenth Edition. USA: Pearson Education.

Hatch \&Farhady. 1982. Research Design and Statistics for Applied
P-ISSN 2623-0062

E-ISSN 2622-9056

rejected $\mathrm{H}_{0}$. If $\mathrm{T}$ table $\leq \mathrm{T}$ test $\leq \mathrm{T}$ table, the result was $=0.444<3.226>0.444$. it means there was a significant differences of students' reading comprehension between students who are tought through reading narrative text by using LRD strategy and wthout using LRD strategy after they were given treatment. The presentage of score gaining on the control class was $12 \%$ while on the experimental class was $22 \%$. In other words, score gaining on the experimental class is higher than the control class.

Based on the conclusion above, it can be concluded that reading comprehension through LRD strategy was more effective in increasing reading comprehension. In the other words, students' reading comprehension that were taught through LRD strategy was higher than those who

Linguistics. Los Angeles: Newbury House Publications.

Klinger.Sharon.Et.al.2007. Teaching Reading Comprehension to Students with Learning Difficulties. New York: Guilford Press

Manzo\&Ula. 2005. Content Area Reading. A Heurisctic Approach.USA: Merrill Publishing Company.

Mc.Kenna\&Katherine. 2015. Assesment for Reading Instructions. New York: Guilford Press.

Ridwan. 2007. BelajarMudahuntukPenelitian Guru KaryawandanPenelitiMuda, Bandung:

Alfabeta 